\title{
TISSUE FACTOR IN CIRRHOTIC AND HEPATOCELLULAR CARCINOMA PATIENTS
}

\author{
By
Mohamed Mohamed Abd El-Rehim El-Hawawshy, Maged Abd El- Fattah Esmael Shalaby and Ahmed Ali Ali Assem \\ Department of Clinical Pathology, Faculty of Medicine, Al-Azhar University \\ Corresponding author: Mohamed Mohamed Abd El-Rehim El-Hawawshy, \\ E-mail: mohamed-elhawawshy1520@gmail.com
}

\begin{abstract}
Background: The liver is the primary site of synthesis of nearly all coagulation factors, along with several proteins involved in fibrinolysis and anticoagulation, The acute and chronic inflammation in the liver is associated with a bleeding diathesis due to deficiency in the synthesis of coagulation factors as well as a procoagulant state due to the defects in the synthesis of anticoagulant factors by the liver.
\end{abstract}

Objective: To assess the tissue factor in cirrhotic and hepatocellular carcinoma (HCC) patients and their coagulation profile.

Patients and methods: This was a case control study carried on Al-Mahala General Hospital, and conducted on 80 subjects. They were categorized into in to main two groups: Group A (60 patients) and Group B (20 control persons) from March 2019 till September 2019.

Results: There was a statistical significant difference between tissue factor expression and other laboratory parameters among the studied group. There was a significant positive correlation between tissue factor and alanine aminotransferase (ALT), aspartate aminotransferase (AST), creatinine, total bilirubin, $\alpha$-fetoprotein (AFP), international normalized ratio (INR) and activated partial thromboplastin time (APTT). Also there was a significant negative correlation between tissue factor and hemoglobin, albumin and platelets.

Conclusion: Tissue factor (TF) enhances the inflammatory process within the liver parenchyma as it induces release of pro-inflammatory cytokines. This raises the possibility of a potential role for anti-inflammatory substances as a potential therapeutic option that can ameliorate liver damage in those patients.

Keywords: Liver, Coagulation profile, Cirrhotic, Tissue factor.

\section{INTRODUCTION}

The liver is the primary site of synthesis of nearly all coagulation factors, along with several proteins involved in fibrinolysis and anticoagulation (Kopec and Luyendyk, 2014). Chronic active hepatitis and the consequent cirrhosis are severe hepatic parenchymal diseases with potentially life-threatening complications. The acute and chronic inflammation in the liver is associated with a bleeding diathesis due to deficiency in the synthesis of coagulation factors as well as a procoagulant state due to the defects in the synthesis of anticoagulant factors by the liver (Gursoy et al., 2010).

This is increasingly recognized as a component of liver disease pathogenesis. The consequence of acute toxic liver injury can include consumptive coagulopathy, whereas in patients with chronic liver disease and/or cirrhosis, a 
rebalanced, but unstable hemostatic state can easily shift to either hypo-or hypercoagulability (Kopec and Luyendyk, 2014).

Routine diagnostic tests of coagulation, such as the prothrombin time (PT) and the activated partial thromboplastin time (APTT), are frequently prolonged in patients with chronic liver disease suggesting that these patients would be prone to bleeding (Lisman et al., 2010). However, an increasing number of studies indicate that these abnormal findings in routine coagulation tests do not necessarily predict an increased bleeding tendency in patients with chronic liver disease (Tripodi and Mannucci, 2011). Rather, a lot of findings indicate a thrombotic risk in these patients (Anstee et al., 2011).

The coagulation protease thrombin and protease activated receptors (PARs) have been implicated in various facets of liver pathology in rodents. Moreover, a lot of studies suggest that coagulation is associated with morbidity and mortality in patients with chronic liver disease (Stravitz et al., 2013). Therefore, understanding coagulation cascade perturbations in the context of acute and chronic liver disease is important. As the plasma levels of tissue factor (TF) and thrombomodulin (TM) may reflect the status of a plasmatic procoagulatory or anticoagulatory activity and endothelial cell damage, both might be involved in the pathogenesis of bleeding or thromboembolic complications in these patients (Villa et al., 2012).

Tissue factor is the transmembrane receptor for coagulation factor VII/VIIa and the primary activator of the blood coagulation cascade. Tissue factor plays a central role in the hemostatic response to vessel injury and is expressed at high levels to limit bleeding in critical organs/tissues including brain, heart, lungs, kidney, and placenta (Tilley and Mackman, 2010). At the cellular level, restricting expression of tissue factor to extravascular cells prevents inappropriate clotting, but also keeps tissue factor in a position juxtaposed to blood in order to rapidly activate coagulation secondary to loss of vascular integrity (Kopec and Luyendyk, 2014).

Tissue factor can be found in low(also called encrypted) and high- activity (also called deencrypted) states, which is thought to be due to differences in the conformation of TF. TF is constitutively expressed by cells within and surrounding the blood vessel wall, such as vascular smooth muscle cells, pericytes and adventitial fibroblasts (Mackman, 2011).

The aim of this work was to assess the tissue factor and their coagulation profile in cirrhotic and HCC patient.

\section{PATIENTS AND METHODS}

This was a case control study carried on Al-Mahala General Hospital and conducted on 80 subjects. They were categorized into two main groups; Group A (60 case patients). Diagnosis was based on clinical criteria and Group B (20 control subjects) matched with age, gender and socioeconomic standard of patients.

All selected participants received comprehensive information regarding objective and the expected benefit of the study. All ethical considerations were 
taken throughout the whole work and every subject gave an informed consent.

\section{Inclusion Criteria:}

Age > 30years old, male and female patients, hepatitis $\mathrm{C}$ virus related cirrhotic patients classified by child Pugh score (class a, b, c), hepatocellular carcinoma patients and some patients have fibrosis, some have esophageal varices while others have both.

\section{Exclusion Criteria:}

Autoimmune hepatitis, hepatitis B virus positive patients, patients with bilharziasis, patients with autoimmune diseases and abnormal kidney functions.

\section{All patients were subjected to the following:}

1. Clinical assessment: a) History and b) Clinical examination.

2. Laboratory assessment: (routine and general evaluation tests).

3. Radiological assessment: Abdominal ultrasonography (US). Abdominal Contrast-enhanced computed tomography (CT) scan in HCC patients.

\section{Human Tissue factor (TF):}

\section{Principle of the test:}

Sample collection: technique. Accurate coagulation studies depend on the correct whole blood to anticoagu $\neg$ lant ratio. For blood specimens with hematocrits (HCT) of $<55 \%$ (normal), 9 parts of freshly collected whole blood should be immediately added to one part anticoagulant. For blood specimens with hematocrits outside the normal range, adjust the amount of whole blood added to the anticoagulant according to the following formula:

Part whole blood to one part of anticoagulant $=\{0.6 \div(1$-het $)\} \times 9$ (Grgac et al., 2013).

Particular care should be taken when using evacuated test tubes. These tubes are designed to draw 9 parts blood to 1 part anticoagulant. If the hematocrit is determined abnormal, blood should be drawn into a syringe and an appropriate amount mixed with an adjusted volume of citrate anticoagulant.

A Pilot study was carried out on $(10 \%$ of study sample) to test feasibility, applicability and clarity of methods.

\section{Statistical analysis:}

Analysis of data was done using Statistical Package for the Social Sciences version 20 (SPSS Inc., Chicago, IL, USA). Quantitative variables were described in the form of mean, standard deviation and range. Qualitative variables were described as number and percent. In order to compare parametric quantitative variables between the groups, One-way ANOVA was performed. Qualitative variables were compared using chi-square (X2) test or Fisher's exact test when frequencies were below five. Pearson correlation coefficients were used to assess the association between two normally distributed variables. When a variable was not normally distributed, A P value $<0.05$ wer considered significant. ANOVA test was used in the comparison between each group with each other group if $F$ wer insignificant. 


\section{RESULTS}

There was no statistical significant difference between the two studied groups as regard age and gender (Table 1).

Table (1): Demographic data in between the studied groups

\begin{tabular}{|c|c|c|c|c|c|c|c|}
\hline Parameters & \multicolumn{2}{|c|}{$\begin{array}{l}\text { Control } \\
\text { group } \\
(\mathbf{n}=\mathbf{2 0})\end{array}$} & \multicolumn{2}{|c|}{$\begin{array}{l}\text { Cirrhosis } \\
\text { group } \\
(\mathbf{n = 3 0})\end{array}$} & \multicolumn{2}{|c|}{$\begin{array}{c}\text { Hepatocellular } \\
\text { carcinoma } \\
(\mathbf{n}=\mathbf{3 0})\end{array}$} & $P$ value \\
\hline \multicolumn{8}{|l|}{ Age: (years): } \\
\hline $\begin{array}{l}\text { Mean } \pm \text { SD } \\
\text { Range }\end{array}$ & \multicolumn{2}{|c|}{$\begin{array}{c}55.15 \pm 10.1 \\
(35-74)\end{array}$} & \multicolumn{2}{|c|}{$\begin{array}{c}52.66 \pm 10.73 \\
(33-74)\end{array}$} & \multicolumn{2}{|c|}{$\begin{array}{l}55.10 \pm 8 \\
(35-74)\end{array}$} & 0.547 \\
\hline & No. & $\%$ & No. & $\%$ & No. & $\%$ & P value \\
\hline \multicolumn{7}{|l|}{ Gender: } & \\
\hline $\begin{array}{l}\text { Female } \\
\text { Male }\end{array}$ & $\begin{array}{c}7 \\
13 \\
\end{array}$ & $\begin{array}{l}35.0 \\
65.0\end{array}$ & $\begin{array}{l}11 \\
19 \\
\end{array}$ & $\begin{array}{l}36.7 \\
63.3 \\
\end{array}$ & $\begin{array}{l}15 \\
15 \\
\end{array}$ & $\begin{array}{l}50.0 \\
50.0 \\
\end{array}$ & 0.643 \\
\hline
\end{tabular}

$\mathrm{F}$ is for one way ANOVA, X2 for chi square test.

There was a significant difference between the studied groups as regard ALT and AST levels. Also, there was significant difference total bilirubin, INR, albumin, creatinine, platelets, AFP, Hemoglobin and aPTT (Table 2). 
Table (2): Clinical and laboratory data in between the studied groups

\begin{tabular}{|c|c|c|c|c|}
\hline Parameters & $\begin{array}{c}\text { Control group } \\
(\mathbf{n}=\mathbf{2 0})\end{array}$ & $\begin{array}{c}\text { Cirrhosis group } \\
\qquad(\mathbf{n}=\mathbf{3 0})\end{array}$ & $\begin{array}{l}\text { Hepatocellular } \\
\text { carcinoma } \\
(\mathbf{n}=\mathbf{3 0})\end{array}$ & $P$ value \\
\hline \multicolumn{5}{|l|}{ AFP: } \\
\hline $\begin{array}{l}\text { Mean } \pm \text { SD } \\
\text { Range }\end{array}$ & $\begin{array}{c}1.37 \pm 0.33 \\
0.5-3.1\end{array}$ & $\begin{array}{c}1.79 \pm 0.59 \\
0.4-3.5\end{array}$ & $\begin{array}{c}784.56 \pm 130.7 \\
85-1852\end{array}$ & $<0.001$ \\
\hline \multicolumn{5}{|l|}{ Albumin : } \\
\hline $\begin{array}{l}\text { Mean } \pm \text { SD } \\
\text { Range }\end{array}$ & $\begin{array}{c}4.44 \pm 0.35 \\
3.9-5\end{array}$ & $\begin{array}{c}2.87 \pm 0.70 \\
1.7-3.9\end{array}$ & $\begin{array}{c}2.02 \pm 0.23 \\
1.7-2.4\end{array}$ & $<0.001$ \\
\hline \multicolumn{5}{|l|}{ ALT : } \\
\hline $\begin{array}{l}\text { Mean } \pm \text { SD } \\
\text { Range }\end{array}$ & $\begin{array}{c}12.55 \pm 1.98 \\
10-17\end{array}$ & $\begin{array}{c}21.64 \pm 3.95 \\
16-86\end{array}$ & $\begin{array}{c}113.3 \pm 14.79 \\
81-137\end{array}$ & $<0.001$ \\
\hline \multicolumn{5}{|l|}{ AST: } \\
\hline $\begin{array}{l}\text { Mean } \pm \text { SD } \\
\text { Range }\end{array}$ & $\begin{array}{c}14.05 \pm 2.01 \\
10-17 \\
\end{array}$ & $\begin{array}{c}64 \pm 13.37 \\
25-97 \\
\end{array}$ & $\begin{array}{c}125.8 \pm 15.03 \\
99-148 \\
\end{array}$ & $<0.001$ \\
\hline \multicolumn{5}{|c|}{ Total bilirubin: } \\
\hline $\begin{array}{l}\text { Mean } \pm \text { SD } \\
\text { Range }\end{array}$ & $\begin{array}{c}0.84 \pm 0.14 \\
0.6-1.1\end{array}$ & $\begin{array}{c}2.81 \pm 0.19 \\
0.4-8.5\end{array}$ & $\begin{array}{c}5.58 \pm 1.53 \\
3.6-8.5\end{array}$ & $<0.001$ \\
\hline \multicolumn{5}{|l|}{ INR: } \\
\hline $\begin{array}{l}\text { Mean } \pm \text { SD } \\
\text { Range }\end{array}$ & $\begin{array}{l}1 \pm 0.07 \\
0.9-1.1\end{array}$ & $\begin{array}{c}1.92 \pm 0.58 \\
1-2.8\end{array}$ & $\begin{array}{c}2.59 \pm 0.23 \\
2.4-3.1\end{array}$ & $<0.001$ \\
\hline \multicolumn{5}{|l|}{ aPTT: } \\
\hline $\begin{array}{l}\text { Mean } \pm \text { SD } \\
\text { Range }\end{array}$ & $\begin{array}{c}34.25 \pm 2.24 \\
31-38\end{array}$ & $\begin{array}{c}49.36 \pm 10.61 \\
32-69\end{array}$ & $\begin{array}{c}55.36 \pm 4.31 \\
50-67\end{array}$ & $<0.001$ \\
\hline \multicolumn{5}{|l|}{ Creatinine: } \\
\hline $\begin{array}{l}\text { Mean } \pm \text { SD } \\
\text { Range }\end{array}$ & $\begin{array}{c}0.74 \pm 0.20 \\
0.4-1\end{array}$ & $\begin{array}{c}0.82 \pm 0.23 \\
0.4-1.3\end{array}$ & $\begin{array}{c}1.04 \pm 0.16 \\
0.8-1.3\end{array}$ & $<0.001$ \\
\hline \multicolumn{5}{|c|}{ Haemoglobine: } \\
\hline $\begin{array}{l}\text { Mean } \pm \text { SD } \\
\text { Range }\end{array}$ & $\begin{array}{c}12.94 \pm 0.25 \\
12.5-13.5\end{array}$ & $\begin{array}{c}8.51 \pm 1.50 \\
5.1-10.9\end{array}$ & $\begin{array}{c}7.34 \pm 1.57 \\
2.9-9.7\end{array}$ & $<0.001$ \\
\hline \multicolumn{5}{|l|}{ Platelets $* 10^{3}$ : } \\
\hline $\begin{array}{l}\text { Median } \\
\text { Range }\end{array}$ & $\begin{array}{c}348.6 \pm 52.1 \\
209-437\end{array}$ & $\begin{array}{c}202.8 \pm 89.6 \\
78-389 \\
\end{array}$ & $\begin{array}{c}103.4 \pm 23.3 \\
70-142 \\
\end{array}$ & $<0.001$ \\
\hline
\end{tabular}

$\mathrm{F}$ is for one way ANOVA, $\mathrm{K}$ is for Kruskall-Wallis test

There was a significant difference between the two studied groups as regard $\mathrm{HCVab}$, while there is no significant difference between the two studied groups as regard HBS ag or ANA (Table 3). 
MOHAMED M. A. EL-HAWAWSHY et al.,

Table (3): Immunological analysis of the studied groups

\begin{tabular}{|c|c|c|c|c|c|c|c|}
\hline \multirow{2}{*}{ Parameters } & \multicolumn{2}{|c|}{$\begin{array}{c}\text { Control group } \\
(\mathbf{n}=\mathbf{2 0})\end{array}$} & \multicolumn{2}{|c|}{$\begin{array}{c}\text { Cirrhosis group } \\
\qquad(\mathbf{n}=\mathbf{3 0})\end{array}$} & \multicolumn{2}{|c|}{$\begin{array}{l}\text { Hepatocellular } \\
\text { carcinoma } \\
(\mathbf{n}=30)\end{array}$} & \multirow[t]{2}{*}{ p-value } \\
\hline & No. & $\%$ & No. & $\%$ & No. & $\%$ & \\
\hline \multicolumn{8}{|l|}{ HCV ab: } \\
\hline Negative: & 20 & 100.0 & 0 & 0.0 & 0 & 0.0 & 0001 \\
\hline Positive: & 0 & 0.0 & 30 & 100.0 & 30 & 100.0 & $<0.001$ \\
\hline \multicolumn{8}{|l|}{ HBS ag : } \\
\hline Negative: & 20 & 100.0 & 30 & 100.0 & 30 & 100.0 & \\
\hline Positive: & 0 & 0.0 & 0 & 0.0 & 0 & 0.0 & 1 \\
\hline \multicolumn{8}{|l|}{ ANA: } \\
\hline Negative: & 20 & 100.0 & 30 & 100.0 & 30 & 100.0 & \\
\hline Positive: & 0 & 0.0 & 0 & 0.0 & 0 & 0.0 & 1 \\
\hline
\end{tabular}

About $33.3 \%$ of cases were Child Pugh score B and $33.4 \%$ of cases were Child score A, $33.3 \%$ of cases were Child Pugh Pugh score C (Table 4).

Table (4): Child Pugh score of the studied cirrhosis cases

\begin{tabular}{|c|c|c|}
\hline \multicolumn{3}{|c|}{ Child Pugh score: } \\
\hline & No. & \% \\
\hline A & 10 & 33.3 \\
B & 10 & 33.3 \\
C & 10 & 33.4 \\
\hline
\end{tabular}

There was a significant difference between different Child Pugh classifications as regard tissue. ( Table 5).

Table (5): Comparison between different Child Pugh classification as regard tissue factor

\begin{tabular}{|c|c|c|c|c|}
\hline Classifications & $\underset{(n=10)}{A}$ & $\underset{(n=10)}{\text { B }}$ & $\underset{(n=10)}{\mathbf{C}}$ & P value \\
\hline
\end{tabular}

\section{DISCUSSION}

The present study assessed the demographic characteristics of the participants and found that there was no statistical significant difference between the two studied groups as regard age and gender.

In agreement with the present study, the study of El-Edel et al. (2019) revealed that there is no statistical significant difference between the two studied groups as regard age and gender.

The present study revealed that there was a significant difference between the studied groups as regard ALT and AST, total bilirubin, INR, albumin, creatinine, platelets, tissue factor, AFP, hemoglobin and aPTT. The study of Abu El-Makarem et al. (2017) found that there was highly significant difference between the studied groups as regard total bilirubin, albumin and platelets, also there was significant 
difference regarding ALT. In another study of Elgamal et al. (2018) the laboratory results of the studied groups showed statistically significant difference between HCC group and the other groups with respect to hemoglobin level, white blood cells count, platelet count, aspartate aminotransferase (AST), alanine aminotransferase, albumen level, serum bilirubin, international normalized ratio, and AFP.

El-Edel et al. (2019) showed that liver function tests as reflected by elevated serum aminotransferases, hyperbilirubinemia (both total and direct), hypoalbuminemia and thrombocytopenia were more significantly affected in cirrhotic patients with diabetes compared with those with cirrhosis while the levels were within normal in the control group.

The present study revealed that there was a significant difference between the two studied groups as regard HCVab, while there was no significant difference between the two studied groups as regard HBS ag or ANA.

HCC can be considered a classical inflammation-induced cancer. Hepatitis B and Hepatitis $\mathrm{C}$ infection are known risk factors for the development of HCC. In most cases, patients with chronic viral hepatitis will first develop liver cirrhosis and HCC, however select patients - with chronic HBV infection for example - are at high risk of developing $\mathrm{HCC}$ even in the absence of liver cirrhosis (Greten et al., 2013).

Hepatitis $\mathrm{C}$ virus has emerged as the foremost cause of HCC in many countries and has surpassed hepatitis B virus (HBV) as a significant risk factor for the disease (Kim et al., 2013). In the majority of cases, HCC in hepatitis C occurs following persistent liver insult in the form of chronic hepatic inflammation, advanced fibrosis and cirrhosis. Recently, studies have also shown a direct role for $\mathrm{HCV}$ in cancer promotion with various $\mathrm{HCV}$ proteins demonstrating oncogenic properties (Moriya et al., 2010). Overall, a combination of viral, genetic, host and environmental factors likely influence HCC carcinogenesis. Factors that thus affect or modify the likelihood of HCC development in patients with chronic hepatitis $\mathrm{C}$, have been identified by clinical and epidemiologic studies (Mitchell et al., 2015).

The current study revealed that $33.3 \%$ of cases were Child Pugh score A, 33.3\% of cases were Child Pugh score B and $33.4 \%$ of cases were Child Pugh score C, and found that there was high significant difference between different Child Pugh classification as regard tissue factor.

El-Edel et al. (2019) stated that the levels of TF expression increased progressively with the Child-Pugh class being higher in stage C. El-Bassiouni et al. (2013) and Panasiuk et al. (2010) declared a significant increase in CD142 expression on peripheral blood monocyte in cirrhotic patients with Child $\mathrm{C}$ compared with those with Child A and B.

In agreement with our results, the study of Abu El-Makarem et al. (2017) revealed that the values of TF antigen expression progressively increased from $\mathrm{A}$ to $\mathrm{C}$ child Pugh class. Expression of tissue factor (TF) by tumor cells may be predictive of systemic VTE in patients with pancreatic and ovarian cancers (Khorana et al., 2010). It has been shown that hepatoma cells can synthesize TF and whether this 
results in an increased risk for thrombosis is still unclear, hence the need for additional prospective studies (Poon et al., 2010).

The present study assessed the correlation between tissue factors and other parameters and the results showed that that there was a significant positive correlation between tissue factor and ALT, AST, creatinine, total bilirubin, AFP, INR and Aptt, and a significant negative correlation between tissue factor and Hemoglobin, albumin and platelets. In agreement with our results, the study of El-Edel et al. (2019) revealed that there was a positive correlation between TF expression and serum levels of aspartate aminotransferase, alanine aminotransferase, and bilirubin (both total and direct). On the other hand, there was a negative correlation between TF levels on peripheral monocyte and the albumin level and platelet count. The level of TF expression increased in line with the Child-Pugh class, the highest being in patients with class $\mathrm{C}$.

In contrast to our results, the study of Abu El-Makarem et al. (2017) revealed that Notably, TF expression was correlated positively with liver decompensating events as variceal bleeding, grade $3 / 4$ hepatic encephalopathy and with all parameters except high density lipoprotein had negative correlation with TF. When all the significant results of this univariate analysis were used in a linear regression analysis, variceal bleeding and serum level of TC was independently correlated with monocytic TF expression. This difference can be explained by different numbers of selected populations.
The study found that there was a statistical significant difference between tissue factor expression and other laboratory parameters among the studied group that was in contrast with the results of the study of Tsai et al. (2015) where there was no statistical significant difference between tissue factor expression and other laboratory parameters. This controversy can be explained by different clinical criteria and ethnic backgrounds of selected populations.

Unfortunately, it is still unclear which patients carry a higher risk of developing thrombotic complications and there are no prospective studies on this matter. Given the increased mortality and morbidity associated with thrombotic complications. It is of the utmost importance to assess which patients have a higher risk of thrombosis (portal vein thrombosis and systemic thromboembolic complications) and would therefore most likely benefit from early thrombo-prophylaxis. More precisely, patient-related variables pertaining to liver cancers and its effects (mostly tumor burden, fibrinogen concentration, platelet count, presence of hypercoagulability at viscoelastic tests, TF+MVs), as well as the clinical scenario (cirrhotic patient with HCC waiting for liver transplantation, invasive procedures) should be taken into consideration to ascertain in which cases the benefits of thromboprophylaxis exceed the risk of anticoagulation (Zanetto et al., 2018).

\section{CONCLUSION}

$\mathrm{TF}$ enhances the inflammatory process within the liver parenchyma as it was shown to induce release of proinflammatory cytokines. 


\section{REFERENCES}

1. Abu El-Makarem MA, Atef FE, Moustafa ME, Tahra MS Ragaa AE, Aliaa SA, Douaa MS, Rania MB and Mahmoud AM (2017): Non-neoplastic portal vein thrombosis in hev cirrhosis patients is it an immuno-inflammatory disorder?. Annals of Hepatology, 16 (4): 574-583.

2. Anstee QM, Tripodi A, Sogaard KK, Primignani $M$ and Valla DC (2011): Hypercoagulability in cirrhosis: causes and consequences. J Thromb Haemost., 9: 1713-1723.

3. El-Bassiouni NE, Zayed RA, Metwally BO, Ibrahim AR, Zahran YM, Mohamoud MO and El Messery AE (2013): Tissue factor expression on blood monocytes in patients with hepatitis c virus induced chronic liver disease. Comp Clin Pathol., 23: 1159-1166.

4. El-Edel RH, Abou-El-Ela DH, Osman NF and Salama MF (2019): A study on the relationship between tissue factor expression and liver damage in diabetic patients with hepatitis c virus-related cirrhosis. Menoufia Med J., 32: 267-274.

5. Elgamal S, Ghafar AA, Ghoneem E, Elshaer M, Alrefai $H$ and Elemshaty $W$ (2018): Characterization of patients with hepatocellular carcinoma on the way for early detection: one center experience. Egypt J Intern Med., 30: 231-238.

6. Greten TF, Duffy AG and Korangy F (2013): Hepatocellular carcinoma from an immunologic perspective. Clinical cancer research. Cancer Research, 19(24): 66786685 .

7. Grgac K, Van Zijl PC and Qin Q. (2013): Hematocrit and oxygenation dependence of blood $1 \mathrm{H} 2 \mathrm{O}$ T1 at 7 Tesla. Magnetic Resonance in Medicine, 70(4): 1153-1159.
8. Gursoy S, Bafikol $M$ and Torun $E$ (2010): Importance of anticoagulant proteins in chronic liver diseases. Turk $\mathbf{J}$ Gastroenterol., 16 (3): 129-133.

9. Khorana AA, Ahrendt SA, Ryan CK, Francis CW, Hruban RH, Hu YC, Hostetter G, Harvey J and Taubman MB (2010): Tissue factor expression, angiogenesis and thrombosis in pancreatic cancer. Clin Cancer Res., 13 (10): 28702875.

10.Kim MN, Kim BK and Han KH (2013): Hepatocellular carcinoma in patients with chronic hepatitis $C$ virus infection in the Asia-Pacific region. J Gastroenterol., 48: 681-688.

11.Kopec AK and Luyendyk JP. (2014): Coagulation in liver toxicity and disease: Role of hepatocyte tissue factor. Thromb Res., 133(0 1): 57-59.

12.Lisman T, Caldwell SH, Burroughs AK, Northup PG, Senzolo $M$ and Stravitz RT (2010): Hemostasis and thrombosis in patients with liver disease: The ups and downs. J Hepatol., 53: 362-371.

13.Mackman N (2011): The role of tissue factor and factor VIIa in hemostasis. Anesth Analg., 108: 1447-1452.

14. Mitchell JK, Lemon SM and McGivern DR (2015): How do persistent infections with hepatitis $\mathrm{C}$ virus cause liver cancer? Curr Opin Virol., 14: 101-108.

15.Moriya K, Fujie H, Shintani Y, Yotsuyanagi H, Tsutsumi T, Ishibashi K, Matsuura Y, Kimura S, Miyamura T and Koike $K$ (2010): The core protein of hepatitis $\mathrm{C}$ virus induces hepatocellular carcinoma in transgenic mice. Nat Med., 4: 1065-1070.

16.Panasiuk A, Zak J, Panasiuk $B$ and Prokopowicz D (2010): Increase in expression of monocytic tissue factor (CD142) with monocytes and blood 
platelet activation in liver cirrhosis. Blood Coagul. Fibrinolysis, 18: 739-744.

17.Poon RT, Lau CP, Ho JW, Yu WC, Fan ST and Wong $\mathbf{J}$ (2010): Tissue factor expression correlates with tumor angiogenesis and invasiveness in human hepatocellular carcinoma. Clin. Cancer Res., 9 (14): 5339-5345.

18.Stravitz RT, Bowling R, Bradford RL, Key NS, Glover S and Thacker LR (2013): Role of procoagulant microparticles in mediating complications and outcome of acute liver injury and acute liver failure. Hepatology, 58: 304-313.

19.Tilley $R$ and Mackman $N$ (2010): Tissue factor in hemostasis and thrombosis. Seminars in Thrombosis and Hemostasis, 32: 5-10.

20.Tripodi A and Mannucci PM (2011): The coagulopathy of chronic liver disease. N Engl J Med., 365: 147-156.
21.Tsai MC, Chen KD, Wang CC, Huang $\mathrm{KT}$, Wu CH, Kuo IY and Lin CC (2015): Factor VII promotes hepatocellular carcinoma progression through ERK-TSC signaling. Cell Death Discovery, 1: 1-10.

22.Villa E, Camma C, Marietta M, Luongo M, Critelli $R$ and Colopi $S$ (2012): Enoxaparin prevents portal vein thrombosis and liver decompensation in patients with advanced cirrhosis. Gastroenterology, 143: 1253-1260.

23.Zanetto A, Campello E, Spiezia $\mathbf{L}$, Burra $P$, Simioni $P$ and Russo FP (2018): Cancer associated thrombosis in cirrhotic patients with hepatocellular carcinoma. Cancers, 10 (11): 450-55. 
العامل النسيجى فى مرضى سرطان و تليف الكبد

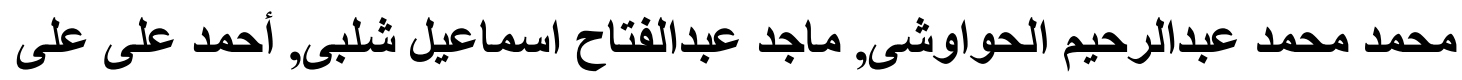
عاصم

قسم الباثولوجيا الإكلينيكية, كلية الطب، جامعة الأزهر

E-mail: mohamed-elhawawshy1520@gmail.com

خلقيـــة البحـــث: المرضـــى المصـــابون بالســـرطان أكتثـر عرضــــة للإصــــابة

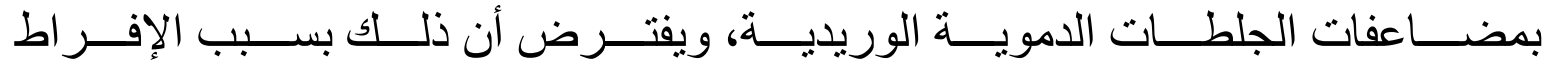

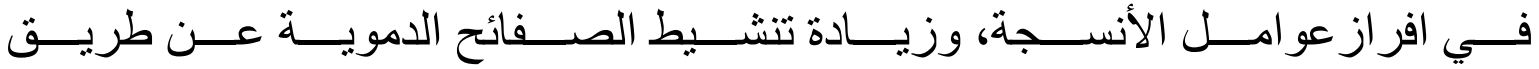

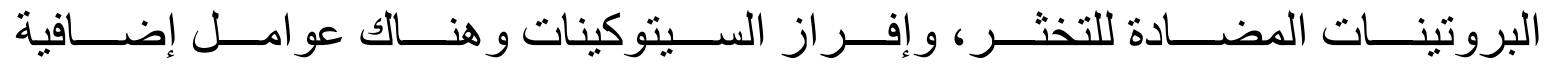

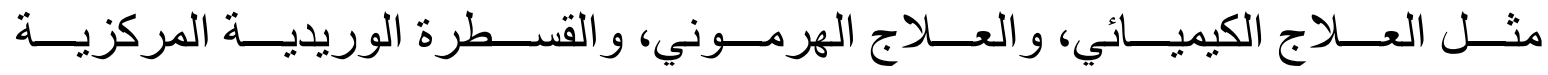

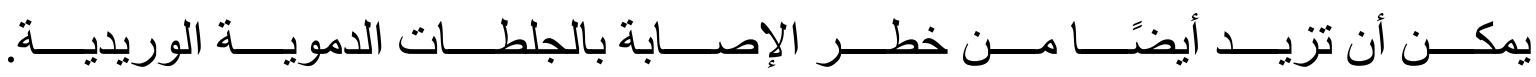

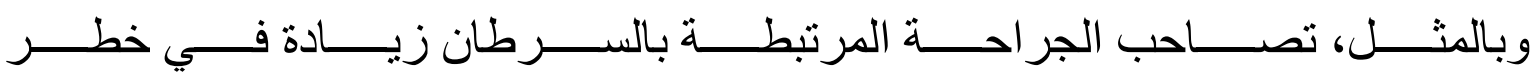

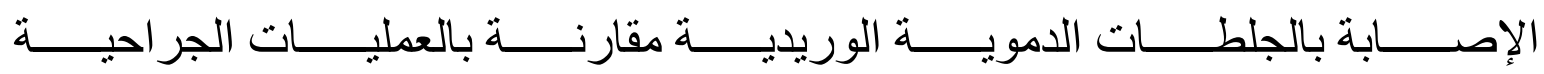
الأخرى. - الإص.

الهــدف مــن البحــث: التقيــيم المتــز امن للعامـلـل النســيجى فــي مرضــى تليــف الكبد وتقييم عو امل التخثر بهم.

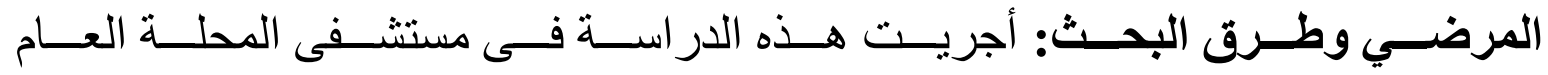

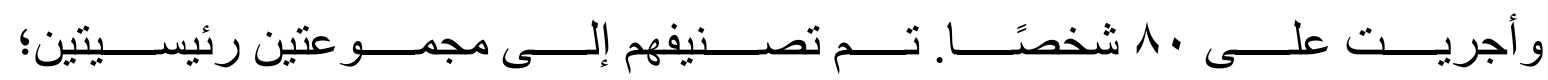

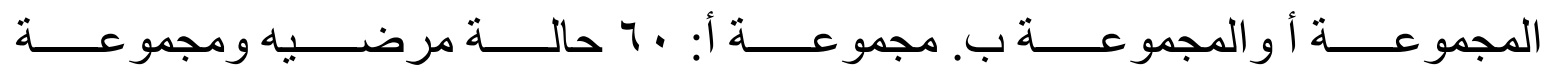

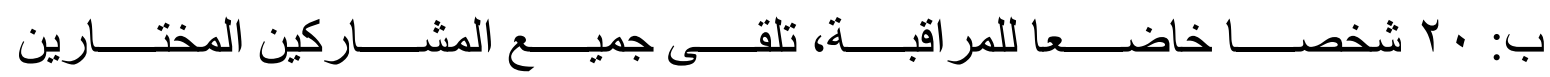

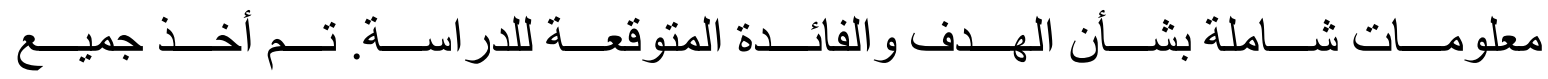
الاعتبار ات الأخلاقية طو ال العمل كله. 


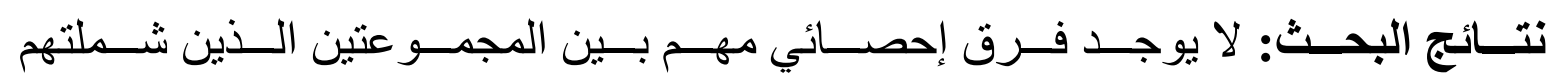

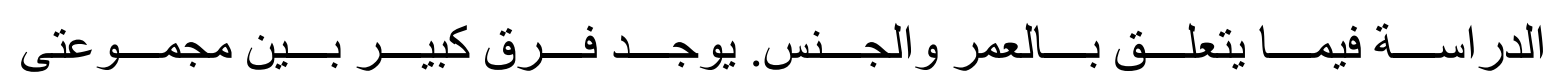

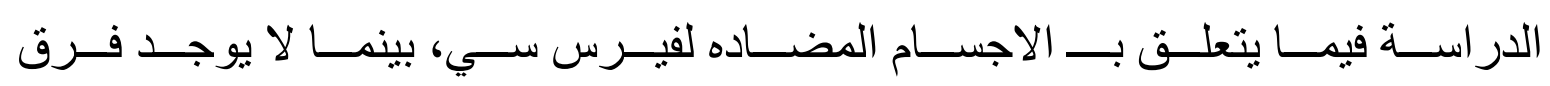

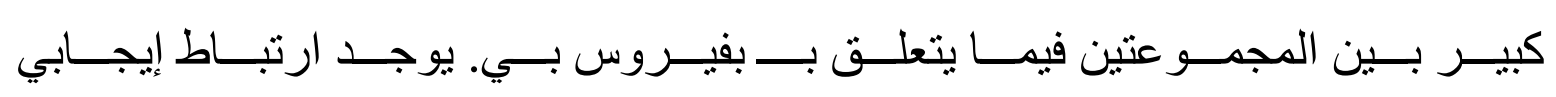

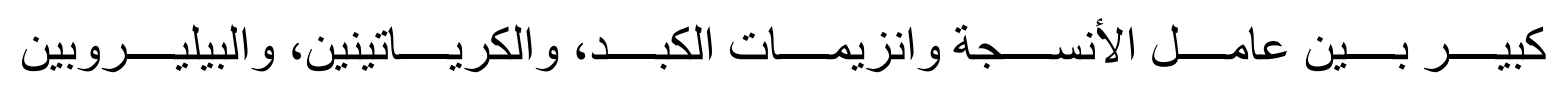

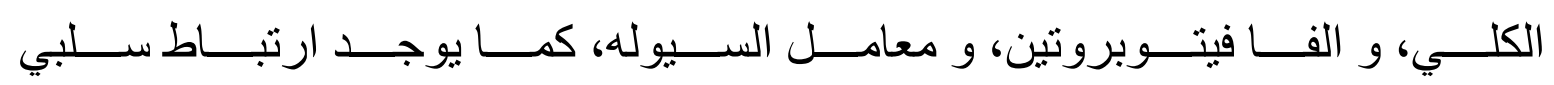

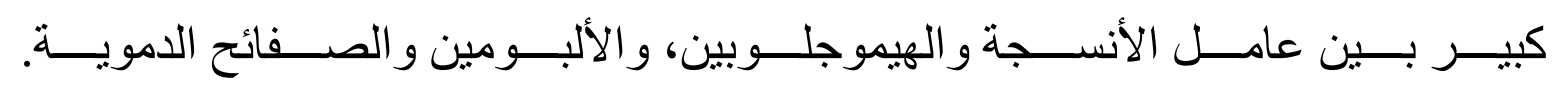

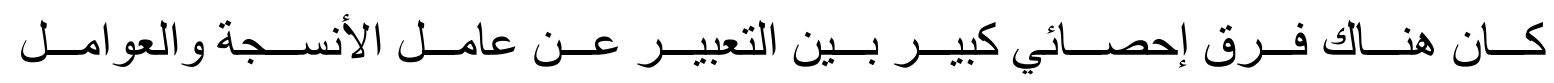
المختبرية الأخرى بين مجموعة الدراسة.

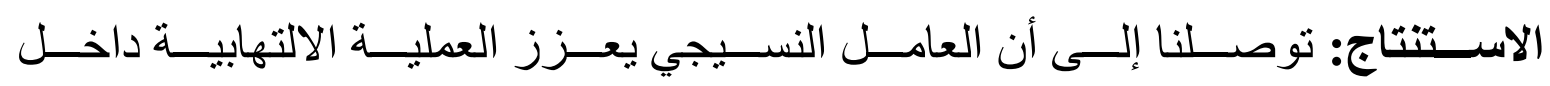

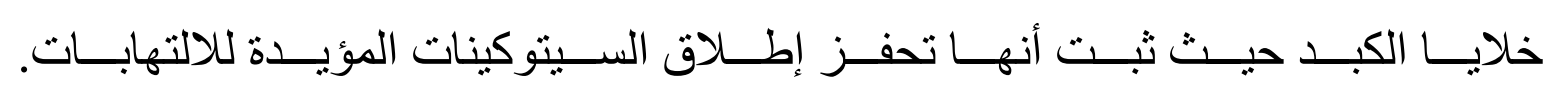

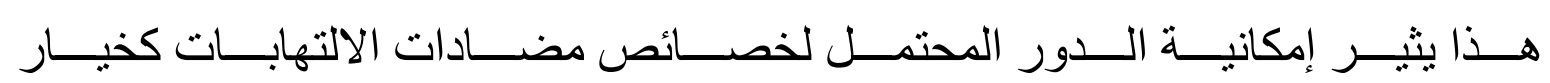
علاجي محتمل يمكن أن يخفف من تلف الكبد في هؤلاء المرضى. الكلمات الدالة: الكبد، ملف تجلط الدم، تليف الكبد، عامل الأنسجة. 